\title{
FEDERACJA BIBLIOTEK KOŚCIELNYCH FIDES W GOŚCINNYCH MURACH BIBLIOTEKI UNIWERSYTECKIEJ KATOLICKIEGO UNIWERSYTETU LUBELSKIEGO JANA PAWLA II. LUBLIN 1-3 WRZEŚNIA 2015 R.
}

W dniach od 1-3 września 2015 roku odbyło się XXI Walne Zgromadzenie Federacji Bibliotek Kościelnych Fides. Gospodarzem spotkania była Biblioteka Uniwersytecka Katolickiego Uniwersytetu Lubelskiego Jana Pawła II w Lublinie. Miejscem pobytu przedstawicieli bibliotek kościelnych Fides i części obrad był dom studencki Uniwersytetu Marii Curie-Skłodowskiej „Helios”, natomiast sesje panelowe odbywały się w Bibliotece Uniwersyteckiej KUL oraz w Bibliotece Wydziału Teologii.

W pierwszym dniu spotkania zebranych gości powitała Barbara Zezula - dyrektor Biblioteki Uniwersyteckiej Katolickiego Uniwersytetu Lubelskiego - wyrażając podziękowanie i radość z przyjęcia w poczet członków Federacji, a także możliwość goszczenia reprezentantów bibliotek kościelnych. Następnie ks. Jerzy Witczak - przewodniczący Federacji Bibliotek Kościelnych Fides i dyrektor Biblioteki Papieskiego Wydziału Teologicznego we Wrocławiu z uznaniem odniósł się do obecności w Federacji największej biblioteki kościelnej w Polsce, przypominając równocześnie lubelskie korzenie założycielskiej grupy Federacji. W dalszej części obrad ks. J. Witczak odczytał protokół z XX Walnego Zgromadzenie Federacji Bibliotek Kościelnych Fides, które odbyło się przed rokiem w Tarnowie oraz przedstawił program bieżącego Walnego Zgromadzenia. Z kolei ks. Tomasz Garwoliński - sekretarz Federacji Bibliotek Kościelnych Fides i Dyrektor Biblioteki Hosianum oraz Biblioteki Wydziału Teologicznego Uniwersytetu Warmińsko -Mazurskiego w Olsztynie przedstawił wniosek Zarządu o nadanie członkostwa honorowego zasłużonym dla bibliotek kościelnych i Federacji oraz zaprezentował sylwetki aplikantów. Wśród tegorocznych kandydatów znaleźli się: o Janusz Kaczmarek OP z Biblioteki Dominikanów w Krakowie, ks. dr Tomasz Kuroń były wieloletni dyrektor Biblioteki Seminaryjnej w Tarnowie, Ks. Kazimierz Rulka emerytowany wieloletni dyrektor Biblioteki Wyższego Seminarium Duchownego we Włocławku, prof. dr hab. Maria Pawłowiczowa emerytowany pracownik na- 
ukowy Uniwersytetu Śląskiego, bp prof. dr hab. Julian Wojtkowski emerytowany biskup diecezji Warmińsko-Mazurskiej, dr Ryszard Żmuda dyrektor Biblioteki Uniwersytetu Medycznego w Łodzi. Walne Zgromadzenie zaaprobowało przedstawione osoby.

Po części oficjalnej był czas na przedstawienie nowych członków Federacji, poinformowanie o zmianach w Zarządzie, podzielenie się wydarzeniami z ostatniego roku. Znaczną część spotkania poświęcono na omówienie przebiegu prac w poszczególnych bibliotekach m.in. w największych bibliotekach kościelnych: BU KUL, Biblioteka UKSW i Biblioteka UP UPJII.

W drugim dniu spotkania po Mszy św. odprawionej w Kościele Akademickim KUL pod przewodnictwem bp Andrzeja Siemieniewskiego - delegata Konferencji Episkopatu Polski ds. Federacji Bibliotek Kościelnych Fides, uczestnicy Walnego Zgromadzenia udali się do Biblioteki Uniwersyteckiej Katolickiego Uniwersytetu Lubelskiego. Sesja Druga została zaplanowana w Czytelni TeologicznoFilozoficznej i poprowadzona przez B. Zazulę, która powitała przybyłych gości zwłaszcza z bibliotek akademickich Lublina oraz innych z ośrodków naukowych w Polsce. Zasadniczą część seminarium poprzedziło wystąpienie ks. J. Witczaka, który przybliżył uczestnikom spotkania genezę Federacji Bibliotek Kościelnych Fides, przypominając równocześnie o dwudziestej rocznicy erygowania Federacji i zwołania I Walnego Zgromadzenia. Przewodniczący omówił najważniejsze wydarzenia z życia bibliotek kościelnych oraz przedstawił dotychczasowe osiągnięcia i poinformował o planach na przyszłość. Następnie głos zabrały pracownice goszczącej nas biblioteki. Doktor Joanna Nastalska-Wiśnicka i Iwona Kasiura w referacie zatytułowanym Lubelskie druki religijne zaprezentowały i omówiły najcenniejsze skarby starodrucznych dokumentów lubelskiej książnicy, wybrane na tę okoliczność ze zbiorów specjalnych. Następnie Anna Krasuska z Oddziału Wydawnictw Ciągłych w swoim wystąpieniu Czasopiśmiennictwo religijne $w$ zbiorach $B U K U L$ omówiła zagadnienie pozyskiwania i gromadzenia czasopism teologicznych oraz współpracę z wieloma ośrodkami myśli teologicznej w kraju i zagranicą. Z kolei dr Artur Hamryszczak z Ośrodka Archiwa Biblioteki i Muzea Kościelne w referacie „Fides Biuletyn Bibliotek Kościelnych” - młodszy brat pótrocznika „Archiwa, Biblioteki i Muzea Kościelne” dokonał analizy wydawniczej i treściowej obydwu periodyków, a także ukazał przydatność tych pism dla środowiska naukowego w prowadzeniu badań źródłowych i dokumentacyjnych .

Tę część obrad zamykał miły akcent wręczenia pierwszemu redaktorowi ks. dr hab. Janowi Bednarczykowi jubileuszowego - czterdziestego zeszytu czasopisma „Fides Biuletyn Bibliotek Kościelnych”. Była to sprzyjająca okoliczność do podziękowania ks. J. Bednarczykowi za długoletnią redakcyjną pracę, twórczy wkład i trud wydawniczy. Zaplanowana przerwa była okazją do nawiązania kontaktu z pracownikami Biblioteki Uniwersyteckiej KUL, wymianą doświadczeń i budowania relacji z zaproszonymi gośćmi.

Trzecią sesja poprowadziła dr Bogumiła Warząchowska - wiceprzewodniczącą Zarządu Federacji oraz kierownik Biblioteki Teologicznej Uniwersytetu Śląskiego w Katowicach. Pierwszy referat zatytułowany Biblioteka Uniwersytecka 
KUL wczoraj $i$ dziś wygłosiła Barbara Zezula. Prelegentka zapoznała słuchaczy z początkami tworzącej się biblioteki w odrodzonym państwie Polskim, specyfiką gromadzonych zbiorów i sposobami pozyskiwania literatury. W wystąpieniu położyła akcent na wkład i zaangażowanie kolejnych dyrektorów w rozwój biblioteki, a także podkreśliła współpracę z innymi uczelniami teologicznymi. Następnie dr Anna Zmorzanka przedstawiła projekt realizowany przez zespól pracowników Czytelni Teologiczno-Filozoficznej i Czytelni Głównej BU KUL w zakresie tworzenia bibliografii dokumentów papieskich z uwzględnieniem tekstów, przekładów i omówien. Zaprezentowana baza zawiera ponad dziewięćset rekordów bibliograficznych, które zaplanowano umieścić w Lubelskiej Bibliotece Wirtualnej oraz przekierować do Elektronicznej Bibliografii Nauk Teologicznych.

W dalszej części obrad ks. dr J. Witczak przedstawił sprawozdanie z rocznej działalności Zarządu, uwzględniając robocze spotkania dotyczące prac redakcyjnych nad półroczniakiem „Fides Biuletyn Bibliotek Kościelnych” oraz opracowaniem programu na kolejne Walne Zgromadzenie, a także indywidualne aktywności członków Zarządu. Z kolei ks. T. Garwoliński odczytał Uchwałę Walnego Zgromadzenia $\mathrm{w}$ sprawie nadania honorowego członkowstwa sześciu wytypowanym osobom, którzy poszerzyli grono dwudziestu dwóch uhonorowanych. Dyplomy zostały wręczone obecnym na sali członkom honorowym, natomiast nieobecnym przedstawiciele Zarządu wręczą osobiści.

Kolejnym punktem Walnego Zgromadzenia było zwiedzanie Biblioteki Uniwersyteckiej KUL, a zwłaszcza Oddziału Reprografii i Digitalizacji Zbiorów oraz Oddziału Zbiorów Specjalnych, a w nim wystawy Skarby Biblioteki KUL z najcenniejszymi dokumentami piśmienniczymi książnicy. Przedstawiciele bibliotek kościelnych podziwiali również dwie inne wystawy. Jedna z nich zatytułowana Od Narodzenia do Zmartwychwstania propaguje siedemsetletnie dziedzictwo kulturalne Lublina, a druga stała ekspozycja pod tytułem Biblioteka Uniwersytecka KUL przed stuleciem istnienia przybliża historię książnicy udokumentowaną na biało-czarnych fotografiach.

W przygotowanym programie znalazło się również miejsce na zwiedzanie zabytków Lublina, w tym Kaplicy Trójcy Świętej na Zamku Lubelskim, Galerii Malarstwa Polskiego w Muzeum, Starego Miasta z zabytkowymi budowlami oraz najstarszych kościołów i Archikatedry z cudownym obrazem Matki Boskiej Płaczącej.

Czwartą sesję w drugim dniu obrad poprowadził o. Grzegorz Filipiuk - przewodniczący komisji rewizyjnej Walnego Zgromadzenia oraz dyrektor Archiwum i Biblioteki Zgromadzenia Ojców Kapucynów w Zakroczymiu. Ta część spotkania dotyczyła sprawozdania z prac poszczególnych członków Zarządu. Ks. dr Wacław Umiński - skarbnik Federacji, a także dyrektor Biblioteki Księży Misjonarzy w Krakowie przedstawił sprawozdanie rzeczowo-finansowe $\mathrm{z}$ ostatniego roku. Dr Bogumiła Warząchowska - redaktor naczelny „Fides Biuletyn Bibliotek Kościelnych" omówiła prace redakcyjne nad periodykiem, zachęcając do publikowania na jego łamach oraz wręczyła egzemplarze pisma autorom bieżących zeszytów. Ks. Tomasz Garwoliński wysunął propozycję zorganizowania warsztatów we współpracy z Zakładem Konserwacji Papieru i Skóry UMK w Toruniu w zakresie ochrony i konserwacji starych druków. Dalsza część obrad koncentrowa- 
ła się wokół bieżących spraw członków Federacji, zwłaszcza wspólnego katalogu w systemie KOHA, gromadzenia i kompletności czasopism oraz szkoleń dla nowo przyjętych do Federacji bibliotek

W trzecim dniu Walnego Zgromadzenia po Mszy św. w kościele Akademickim, uczestnicy spotkania udali się do Auli Wydziału Teologicznego Collegium Jana Pawła II. Piątą sesję poprowadził ks. T. Garwoliński, witając tych, którzy w ostatnim dniu zaszczycili nas swoją obecnością. Następnie dyrektor B. Zezula przedstawiła kierowników oddziałów przybyłych na spotkanie oraz przedstawicieli bibliotek specjalistycznych informując pokrótce o specyfice ich prac i prowadzonej działalności. Sesję wykładową rozpoczął ks. J. Witczak z referatem: Informacje o katalogu wspólnym FIDES w którym zaprezentował centralny katalog Fides i omówił prace z tym związane. Z kolei o Janusz Kaczmarek z Biblioteki Dominikanów w Krakowie przybliżył temat: Znaczenie standaryzacji w katalogach w kontekście wspótpracy z NUKAT, w którym rozwinął spójność danych w katalogach bibliotecznych. Natomiast Katarzyna Mituś - bibliotekarz systemowy centralnego katalogu Fides i pracownik Biblioteki Księży Misjonarzy w Krakowie wystąpiła z tematem Informacja o Deskryptorach Biblioteki Narodowej, w którym przedstawiła rozwój prac w zakresie deskryptórw prowadzonych w Bibliotece Narodowej. Ponownie głos zabrał ks. J. Witczak, który poinformował o planach rozwoju Elektronicznej Bibliografii Nauk Teologicznych, zachęcając do retrospektywnego uzupełniania brakujących czasopism i wydawnictw ciągłych w bazie bibliograficznej

Kolejnym punktem obrad było przedstawienie przez o G. Filipiuka przewodniczącego komisji rewizyjnej sprawozdania z prac komisji, a następnie poprzez głosowanie uprawnionych członków Walnego Zgromadzenia do udzielenie Zarządowi absolutorium.

W końcowej części sesji głos zabrał towarzyszący przez wszystkie dni obrad bp A. Siemieniewski, który z uznaniem odniósł się do prowadzonej działalności, dziękując za przygotowany program i możliwość wysłuchania interesujących tematów. Z kolei ks. J. Witczak podsumowując spotkanie wyraził podziękowanie wszystkim przybyłym członkom Federacji i zaproszonym gościom, a szczególnie gospodarzom za zaangażowanie, trud przygotowań i perfekcyjny przebieg obrad.

Korzystając z gościnnego miejsca spotkania na Wydziale Teologicznym KUL, była okazją do zwiedzenia macierzystej biblioteki, wysłuchania jej historii jako najstarszej biblioteki specjalistycznej Uniwersytetu, poznania specyfiki gromadzonych zbiorów oraz standardów bieżącego funkcjonowania.

Miłym akcentem zamykającym obrady było umożliwienie zwiedzenia wystawy przygotowanej w Muzeum Uniwersyteckim na stulecie Katolickiego Uniwersytetu Lubelskiego Ekspozycja przedstawia dzieje pierwszej lubelskiej uczelni, najważniejsze wydarzenia z jej życia oraz ludzi, którzy przyczynili się do jej rozwoju.

Dwudzieste pierwsze Walne Zgromadzenie Federacji Bibliotek Kościelnych Fides po raz kolejny potwierdziło konieczność spotkań środowiska bibliotekarzy bibliotek kościelnych, ich integrację, wzajemną pomoc oraz wymianę doświadczeń. Miejsce przyszłorocznego spotkania nie zostało jeszcze określone, z otwartością czekamy na zaproszenie do kolejnej książnicy kościelnej. 